\title{
Gender in Audit Committee and Financial Reporting Timeliness: The Case of Unique Continental European Model
}

\author{
Zaitul, Desi Ilona
}

\begin{abstract}
The goal of the current research is to identify whether or not the gender of Audit Committee members affects the timeliness of financial reporting. Unlike several studies which have focused on gender in the Board of Directors, the current study more specifically discusses gender in the Audit Committee in a country which adopts a Continental European System. This study employs panel data analysis for

370 observations of 185 Indonesian listed companies in the 2014-2015 period. This research reports that gender of the Audit Committee members is still debatable with regards to their role in improving the timeliness of financial reporting. Further, size, independence, expertise, and Audit Committee activities have an insignificant impact on the timeliness of financial reporting.
\end{abstract}

Index Terms: Gender in Audit Committee; Financial Reporting Timeliness; Indonesia.

\section{BACKGROUND OF THE STUDY}

Timely information and full disclosure of financial reporting may create capital market efficiency by minimizing information asymmetry among stakeholders and better decision-making (Alkhatib \& Marji, 2012). It can be stated that timeliness is useful information for investors, regulators and other stakeholders. The timeliness of financial reporting means the number of days from the date of the annual report until the date of submitting the annual report to stakeholders (Chambers \& Penman, 1984; Davies $\&$ Whittred, 1980). Timeliness of accounting information is still a highly debated issue among regulators, academics, audit firms, market participants, public companies and investors in developed countries (Abernathy, Beyer, Masli, $\&$ Stefaniak, 2014). However, there is lesser priority given to this aspect in developing countries (Alfraih, 2016).

The factors that affect timeliness of financial reporting have been previously studied by several experts (e.g., Abernathy, Beyer, Masli, \& Stefaniak, 2014; Baatwah, Salleh, \& Ahmad, 2015; Bin Ghanem \& Ariff, 2016; Samaha \& Khlif, 2017). Owusu-Ansah (2000) stated that financial reporting timeliness is a critical tool to lessen rumours, insider trading activity and leaks in the developing market. Chambers \& Penman (1984) perceived that timely financial reporting gives investors high quality information

Revised Manuscript Received on September 22, 2019.

Zaitul, Economics Faculty, Universitas Bung Hatta, Padang, Indonesia

Desi Ilona, Economics Faculty, Universitas Putra Indonesia YPTK, Padang, Indonesia, Desiilona@Upiyptk.Ac.Id. and it can increase pricing securities. Further, the efficient functioning of the capital market in stock valuation is assisted by timeliness of financial reports. Previous studies by Abernathy, Beyer, Masli, \& Stefaniak (2014) have concentrated on financial experience of the Audit Committee members. Baatwah, Salleh, \& Ahmad (2015) verified the effect of the CEO's demographic characteristics in terms of tenure and financial expertise on financial reporting timeliness.

Investigation on financial reporting timeliness consists of two areas: antecedents and consequences of the financial reporting timeliness (e.g., Chambers \& Penman, 1984). Research on the antecedents of financial reporting timeliness has been conducted by many scholars. They utilized various perspectives, such as monitoring cost (Owusu-ansah, 2000); client service and preparation (Ashton, Graul, \& Newton, 1989); and competing size (Cullinan, 2003). The traditional perspective concentrates on the contract between owners and agents (Jensen \& Meckling, 1976). Thus, owners assign formal monitoring mechanisms to monitor the agent's behavior (Fama \& Jensen, 1983). One such mechanism is the Audit Committee.

The Audit Committee first made its appearance in Indonesia in 2000. The Audit Committee is one of the internal mechanisms of corporate governance. One of its main functions is to monitor the financial reporting process. The Audit Committee is also a central part of the decision control system to evaluate the board of directors (Fama \& Jensen, 1983); a key factor in the process of financial reporting (Chandar, Chang, \& Zheng, 2012); and it also helps to detect financial reporting fraud (Vanasco, 1994). Studies on the Audit Committee's role in financial reporting timeliness has been previously undertaken by researchers (e.g., Al-Shaer, Salama, \& Toms, 2017; Bin-Ghanem \& Ariff, 2016; Ika \& Ghazali, 2015; Schmidt \& Wilkins, 2013; Ammer \& Ahmad Zaluki, 2017). Ika \& Ghazali (2015) measured the effectiveness of the Audit Committee using 211 Indonesian companies through four dimensions: composition, authority, resources and the diligence of Audit Committee members. However, prior studies on the gender of Audit Ccommittee members and their effectiveness are scant. Schmidt \& Wilkins (2013) examined Audit Committee dimensions on disclosure timeliness. They noted that Audit Ccommittee expertise is

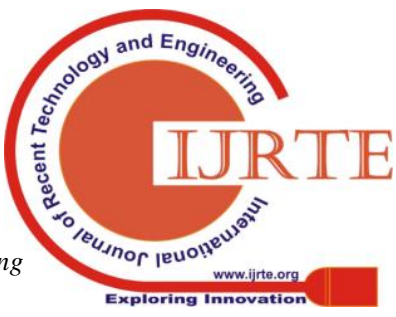


associated with timely disclosure. However, Sulaiman (2017) concluded that the results of prior studies on Audit Ccommittee characteristics are still inconclusive. Abernathy et al. (2014) and Abernathy, Beyer, Masli, \& Stefaniak (2015) explored the contribution of financial expertise of Audit Ccommittee members as a proxy of Audit Ccommittee effectiveness in enhancing the timeliness of financial reporting. They found that financial reporting timeliness could be enhanced if the Audit Committee is more effective in monitoring the board of directors.

Governance and decision-making of a company could improve when women are appointed as Audit Committee members (Arayssi, Dah, \& Jizi, 2016). Several countries, such as the USA, UK, Spain and Malaysia, have revised their corporate governance code by mandating the appointment of women as board members in listed companies (Ammer \& Ahmad-Zaluki, 2017). In addition, Terjesen, Sealy, \& Singh (2009) argued that there is increasing attention being given to the role of women on the board. This phenomenon is also occurring in China where Jin, Song, \& Yang (2014) argued that the number of women appointed to the board is increasing. Until now, Indonesia does not have regulations that govern the appointment of female board members. Ilona (2015) identified that the percentage of women for the period of 2004 to 2010 was only $8.95 \%$ and $9.92 \%$ on the Supervisory Board and the Board of Directors, respectively, for 283 Indonesian listed companies. Even though the male/female population is almost the same, the number of female board members in Indonesia is low. Other studies, such as Carter, D'Souza, Simkins, \& Simpson (2010) and Ahmad-Zaluki (2012) have also concluded that the number of women on the board is very much lower than their male counterparts.

Jin, Song, \& Yang (2014) stated that the issue of the gender of directors has received a great deal of attention from practitioners and academicians. However, the function of women on the board has not been adequately studied. For example, Joecks, Pull, \& Vetter (2013) concluded that there is inconclusive finding regard- ing the relationship of women directors and company performance. Nielsen \& Huse (2010) noted that this issue needs more research to investigate the role of women as board members. Terjesen, Sealy, \& Singh (2009) concluded that research on women on the board has been more descriptive in nature and lacking in theory. Furthermore, most studies on the role of women on the board have been done in a western setting (Hawarden \& Marsland, 2011) with only a few studies examining the gender of the Audit Committee members (Ammer \& Ahmad-Zaluki, 2017; Thiruvadi, 2012). In addition, most researchers have focused on gender of the board directors (Cooper, 2017; Dalton \& Dalton, 2010; Rhee \& Sigler, 2015). Thus, this study is interested to explore the effect of gender of the Audit Committee members in enhancing financial reporting timeliness. It is conducted in Indonesia's listed companies which follow the Continental European system.

The remainder of this work is structured as follows. The next section discusses the theoretical aspects and hypothesis development on the timeliness of financial reporting and gender of the Audit Committee members. This is followed by the explanation of the methodology and measurement of each variable in the third section. Results and discussion are in the fourth section followed by conclusion and recommendations in the fifth session.

\section{THEORETICAL ASPECT}

\section{A. Financial Reporting Timeliness}

Financial reporting timeliness is one of the qualitative attributes of financial reports. It is perceived as an important tool by investors and regulators to evaluate the adequacy of the financial reporting policy (Samaha \& Khlif, 2017; Schmidt \& Wilkins, 2013). According to Hakanson (1977), financial reporting timeliness could dismiss the value of public disclosures which are associated with share price. As others have highlighted (Carslaw \& Kaplan, 1991; Jaggi \& Tsui, 1999), financial reporting timeliness requires that information should be available to users of financial reporting as rapidly as possible and it plays an important role in reducing the asymmetric dissemination of financial information. Further, timely reporting can enhance decision-making and reduce information asymmetry in the stock market (Owusu-Ansah \& Leventis, 2006).

The research on financial reporting timeliness has focused on auditor attributes, governance structure and internal control, company attributes and external to company variables. Determinants of financial reporting timeliness from corporate governance structure and mechanism have been documented, such as Audit Committee characteristics (Abernathy et al., 2015; Ika \& Ghazali, 2015); board directors' experiences (Abdelsalam \& Street, 2007); board shareholding (Niu, 2006); board composition (Beekes, Pope, \& Young, 2004); CEO characteristics (Baatwah, Salleh, \& Ahmad, 2013); and audit committee attributes (Samaha \& Khlif, 2017).

\section{B. Audit Committee}

The Audit Committee is a committee under the Supervisory Board and assists the Supervisory Board. The role of both the Supervisory Board and the Audit Committee in Indonesia is to monitor and advise according to the provisions under the Continental European system. As described in the agency theory, the interest between agent and principal can be aligned when the Audit Committee effectively monitors the agent. Ammer \& Ahmad-Zaluki (2017) argued that the Audit Committee plays a crucial role in the preparation of the financial report and as an internal control mechanism. Hsu (2007) concluded that the Audit Committee can reduce information asymmetry between insiders and outsiders, thereby mitigating agency problems. The Audit Committee conducts meetings routinely with internal auditors, agents and external auditors to discuss internal control, auditing and financial reporting (Klein, 2002). Dezoort (1998) noted that the reliability of internal control, financial

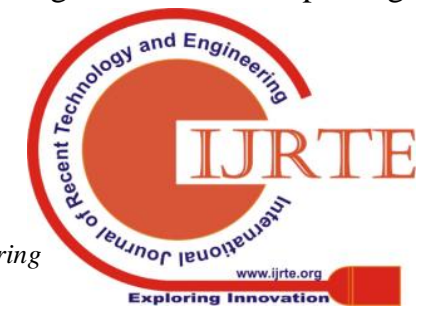


reporting and risk management system depends on the effectiveness of the Audit Committee.

The major responsibility of the Audit Committee is to oversee the Board of Directors (Cohen, Krishnamoorthy, \& Wright, 2004); reduce the possibility of insolvency (Appiah \& Amon, 2017); increase the quality of financial reporting (Al-Shaer and Salama, 2017); ensure better quality of audit (Sulaiman, 2017); and finally, increase company performance (Kallamu \& Saat, 2015). Several previous studies have investigated the role of the Audit Committee in the financial reporting process (e.g., Abernathy, Beyer, Masli, \& Stefaniak, 2015; Defond, Hann, Xuesong, \& Engel, 2005; McMullen, 1996). Defond, Hann, Xuesong, \& Engel (2005) believed that the Audit Committee makes significant contribution to increase the quality of financial reporting, including its timeliness. Further, McMullen (1996) documented that companies with unreliable financial reports are linked to inefficient Audit Committees (Abernathy et al., 2015). It has also been found that the Audit Committee attributes have a significant role in determining financial reporting timeliness. Previous studies have investigated the role of the Audit Committee in terms of its expertise, activities,

size and independence. However, this study focuses on gender, specifically women on the Audit Committee, who may also impact the monitoring effectiveness and company performance. As suggested by Lenard, Yu, York, \& Wu (2014), the contribution of women on the audit committee could reduce fraud.

Early studies on board gender have concluded that female directors are more risk-averse compared to male directors in relation to financial matters and corporate reporting (Betz, O’Connell, \& Shepard, 1989). Offerman \& Armitage (1993) argued that unique attributes of women have been discussed in gender literature. Pelled (1996) concluded that men and women possess different norms, attitudes and beliefs when they make decisions. Hyde \& Kling (2001) argued that women have different expectations of work; they view work as a source of personal development and self fulfilment, while men view it as a career and a means of moving up the hierarchy and securing better compensation. Thus, female directors tend to be better prepared for board meetings than men (Huse, Nielsen, \& Hagen, 2009). In addition, Adams \& Ferreira (2009) concluded that women directors have better attendance records at Audit Committee meetings than men. The attendance record of men has improved because of it. This is supported by Thiruvadi (2012) who believed that meetings and diligence of the Audit Committee members will increase when women are appointed to the Audit Committee. Thus, increasing the number of women in the Audit Committee will enhance monitoring and the quality of financial reporting. In addition, ex- ternal auditors do not need so much time to audit the financial report.Thus, the timeliness of financial reporting could be enhanced.

From the perspective of the resource dependence theory (Zahra \& Pearce, 1989), female participation generates different perspec- tives in terms of advice and counselling.
Daily, Certo, \& Dalton (2000) argued that women bring different viewpoints to the boardroom and facilitate more informed decisions that increase the level of transparanscy at the board level. Erhardt, Werbel, \& Shrader (2003) argued that gender diversity leads to a wider knowledge base. Srinidhi, Gul, \& Tsui (2011) concluded that fe- male directors may improve a board's decision-making, behavior and effectiveness. Some researchers on gender diversity have come to a different conclusion in that diversity can create disagreement and conflict among directors. For example, Adams \& Ferreira (2009) concluded that women on the baord may limit boardroom cohesion, hinder the decision-making process and ruin firm performance. Abdullah (2014) concluded that the potential benefit of women may be fairly limited.

In terms of ethical values, Miethe \& Rothschild (1994) argued that women feel it is their civic responsibility to speak out against wrong-doing and are thus likely to report questionable or illegal acts more frequently than men. Carter, Simkins, \& Simpson (2003) observed that women are likely to display more independent thinking than male directors, which is crucial for effective board oversight. Morrison, Randall, \& Van (2004) ar- gued that women bring a healthy balance to the business compared to men, and tend to behave in a less dictatorial manner. Kaplan, Pany, Samuels, \& Zhang (2009) argued that women judge and behave more ethically. Besides, female directors are more likely to report fraudulent financial reporting. Francoeur, Labelle, \& Sin- clair-Desgagné (2008) concluded that baord gender diversity enforces ethical behavior and supports good governance practices. Rodriquez-Dominguez et al. (2009) paid more attention to ethical concerns.

Gender-diverse baords are more likely to engage in in-depth discussions and exhibit higher quality earnings (Srinidhi et al., 2011). Gul, Srinidhi, \& Ng (2011) concluded that gender diversity on the board could improve the discussion quality at meetings and increase the board's oversight ability more stringently in terms of the firm's transactions, disclosure and reporting. Gavious, Segev, \& Yosef (2012) argued that the presence of women on the board can create a conciliatory atmosphere and increase the sense of moral consideration and ethical standing. In addition, Gavious, Segev, \& Yosef (2012) concluded that there is a significant relationship between accounting aggressiveness and proportion of women in the Audit Committee. Thus, women participation strengthens the legitimacy of the company. In fact, Ren \& Wang (2011) argued that there is pressure to increase gender representativeness in top management teams and on boards from society. From the discussion above, it is clear that women in the Audit Committee can decrease the amount of time needed to sufficiently discuss, comprehend and evaluate accounting policies and unusual transactions with the auditor, therefore reducing the time needed to complete the audit and improve financial reporting timeliness. Therefore, the hypothesis proposed is as follows: 
H1: The presence of women on the Audit Committee improves the timeliness of financial reporting.

\section{RESEARCH METHOD}

This study uses 185 Indonesian listed companies in 2014 and 2015 (370 companies-years) as a sample. The study uses secondary data mainly taken from the annual report and other information sources, such as the company's website. The annual reports are downloaded from www.idx.co.id. Further, the control variables of this research are Audit Committee financial expertise (ACE), Au- dit Committee activities (ACA), Audit Committee independence (ACI), Audit Committee size (ACS), Company age (CA), Company size (CS), Company leverage (CL) and Company profitability (CP).

Timeliness is defined as the number of days between a company's financial year-end and the day on which the company publicly releases its audited financial report (Owusu-ansah, 2000). In contrast to previous studies, this research uses the time of financial report release to the public through the company's announcement on the IDX website (www.idx.co.id). Gender in the Audit Committee is measured by the ratio of number of women to total number of Audit Committee members. Meanwhile, Audit Committee independence and Audit Committee financial expertise are also measured. The total number of Audit Committee members is the proxy for Audit Committee size (Abbott, Parker, \& Peters, 2004). In addition, Audit Committee activities refers to the number of Audit Committee meetings held in a year ( $\mathrm{Lin}, \mathrm{Li}$, \& Yang, 2006). Other control variables are measured by following previous studies. Data is analysed by a panel data approach. Outliers are detected and remedied by Grubbs' (1969) procedure. Classical assumptions, such as normality, are applied first before regression is run (Hair, William, Babin, \& Anderson, 2014). The Breusch-Pagan and Hausmann (Hausman, 1978) tests are used to decide whether the model is pooled OLS, random effect or fixed effect.

\section{RESULT AND DISCUSSION}

This section discusses about the result and discussion of this re- search. Before assessing the normality test, we have to detect any outlier data used in this study. An outlier is an observation that lies outside the overall distribution (Moore \& McCabe, 1999). Usual- ly, outliers can cause data to become not normal and therefore, produce a biased result. There are several techniques to detect and remedy the outliers (e.g. graph method, Grubb Test, etc.). In this study, the case of outliers is detected using the Grubb's extreme studentised deviated test (Grubbs, 1969). The variables are tested one by one. Once an outlier is detected, the value of that outlier is replaced to the second highest value. Grubb's test can detect only one outlier at a time. Therefore, this step must be repeated until no further outliers are detected. First, the mean is calculated and the standard deviation from all values in a particular variable. Second, it calculates the $\mathrm{Z}$ value using that formula. Third, the $\mathrm{Z}$ value is compared to a critical $\mathrm{Z}$ value. The critical $\mathrm{Z}$ value is taken from the statistical table based on the number of observations (Barnet \& Lewis, 1994). The result of this outlier test and Descriptive statistic are demonstrated in Table 1.

Table 1: Result of Outlier and Descriptive Statistic after Remedy

\begin{tabular}{|c|c|c|c|c|c|}
\hline \multirow[t]{2}{*}{ Variables } & \multirow[t]{2}{*}{$\begin{array}{l}\text { Outli- } \\
\text { er }\end{array}$} & \multirow{2}{*}{$\begin{array}{l}\% \\
\text { Outli- } \\
\text { er }\end{array}$} & \multicolumn{3}{|c|}{$\begin{array}{l}\text { Statistic Descriptive } \\
\text { After Rem- edy }\end{array}$} \\
\hline & & & Means & Min & Max \\
\hline TL (days) & 42 & 15.56 & 85.25 & 48.00 & 99.00 \\
\hline ACG (\%) & 0 & 0.00 & 16.00 & 0.00 & 100.00 \\
\hline ACE (\%) & 0 & 0.00 & 42.00 & 0.00 & 100.00 \\
\hline ACA (time) & 23 & 8.52 & 6.35 & 0.00 & 15.00 \\
\hline $\mathrm{ACI}(\%)$ & 0 & 0.00 & 43.00 & 0.00 & 100.00 \\
\hline ACS (person) & 15 & 5.56 & 3.08 & 2.00 & 4.00 \\
\hline CA (years) & 14 & 5.19 & 35.68 & 10.00 & 81.00 \\
\hline $\begin{array}{l}\text { CS (Rp. Tril- } \\
\text { lions) }\end{array}$ & 37 & 13.70 & 29.91 & 1.02 & 370.97 \\
\hline CL $(\%)$ & 0 & 0.00 & 0.45 & 0.00 & 0.96 \\
\hline $\mathrm{CP}(\%)$ & 25 & 9.26 & 0.11 & -0.60 & 0.90 \\
\hline
\end{tabular}

Notes: $\mathrm{TL}=$ Timeliness, $\mathrm{ACG}=$ Audit Committee Gender, ACE: = Audit Committee Financial Expertise, ACA = Audit Committee, Activity, ACI $=$ Audit Committee Independence, $\mathrm{ACS}=$ Audit Committee Size, $\mathrm{CA}=$ Company Age, $\mathrm{CS}=$ Company Size, $\mathrm{CL}=$ Company Leverage, and $\mathrm{CP}=$ Company Profitability.

Early step in multivariate analysis is to screen variables for nor- mality. Normal data is not always required for analysis, but having normally distributed data produces better results compared to non- normally distributed data since normality enhance the analysis (Tabacknick \& Fidell, 1996). This study assesses the normality of variables by using the skewness. Skewness is computed by statis- tic values of skewness divided by standard error. For observation more than 300 , its value exceeds an absolute value of 3.29 (Man- ning \& Munro, 2004). If the distribution of variable is not normal, the transformation process is taking place.

Transformation is a process of creating a new variable through some mathematical operations on score of observations. The result of normality test and transformation are as in Table 2. First, the test of normality using the statistical value of skewness per stand- ard error shows that only one variable (Company leverage) is normal and the rest are not normal. The transformation process was further conducted. The result shows that only five variables are below the cut-off value (below 3.29), i.e., ACS, ACE, ACA, CA and CP. Pallant (2007) argued that the issue of non-normal distribution of variables is frequent in social science research and quite common in research that involves a large sample. In addi- tion, Norusis (1998) and Kleinbaun, Kupper, Muller, \& Nizam (1998) stated that an analysis of variances does not heavily depend on the normality assumption as long as the data are not extremely non-normal. In fact, modest violation of

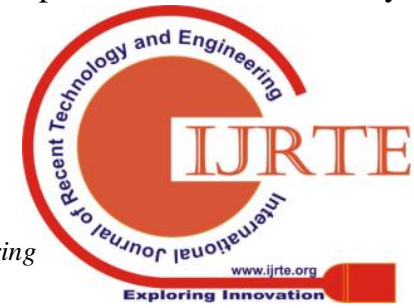


univariate normality is not a problem if the violations are due to skewness and not outliers (Hair et al., 2014). Therefore, the data is free from outliers and other variables which have skewness/standard error value greater than 3.2 (TL, ACI, ACG and CS) and can be tolerated in this study since these variables are free from outliers and their values are not extremely far from the cut-off values.

Table 2: Result of Normality Test and Data Transformation

\begin{tabular}{|c|c|c|c|c|c|c|c|c|}
\hline \multirow{2}{*}{$\begin{array}{l}\text { Variab } \\
\text { les }\end{array}$} & \multicolumn{3}{|c|}{ Skewness } & \multirow{2}{*}{$\begin{array}{l}\text { Decisi } \\
\text { on }\end{array}$} & \multicolumn{4}{|c|}{ Transformation } \\
\hline & $\begin{array}{l}\text { Statis } \\
\text { tic }\end{array}$ & SE & $\begin{array}{l}\text { Stat/ } \\
\text { S E }\end{array}$ & & $\begin{array}{l}\text { Sqr } \\
\mathbf{t}\end{array}$ & Ln & $\begin{array}{l}\mathbf{S} \\
\mathbf{q}\end{array}$ & Inv \\
\hline TL & -1.920 & $\begin{array}{l}0.1 \\
27\end{array}$ & $\begin{array}{l}-15.1 \\
18\end{array}$ & $\begin{array}{l}\text { Not } \\
\text { Norma } \\
1\end{array}$ & $\begin{array}{l}4.8 \\
43\end{array}$ & & & \\
\hline $\mathrm{ACG}$ & 1.196 & $\begin{array}{l}0.1 \\
27\end{array}$ & 9.417 & $\begin{array}{l}\text { Not } \\
\text { Norma } \\
1\end{array}$ & $\begin{array}{l}4.7 \\
79\end{array}$ & & & \\
\hline $\mathrm{ACE}$ & 0.469 & $\begin{array}{l}0.1 \\
27\end{array}$ & 3.693 & $\begin{array}{l}\text { Not } \\
\text { Norma } \\
1\end{array}$ & & $\begin{array}{l}1.065 \\
*\end{array}$ & & \\
\hline $\mathrm{ACA}$ & 0.996 & $\begin{array}{l}0.1 \\
27\end{array}$ & 7.843 & $\begin{array}{l}\text { Not } \\
\text { Norma } \\
1\end{array}$ & & $\begin{array}{l}1.969 \\
*\end{array}$ & & \\
\hline $\mathrm{ACI}$ & 1.018 & $\begin{array}{l}0.1 \\
27\end{array}$ & 8.016 & $\begin{array}{l}\text { Not } \\
\text { Norma } \\
1\end{array}$ & & & & $\begin{array}{l}5.3 \\
89\end{array}$ \\
\hline ACS & 0.701 & $\begin{array}{l}0.1 \\
27\end{array}$ & 5.520 & $\begin{array}{l}\text { Not } \\
\text { Norma } \\
1\end{array}$ & & $\begin{array}{l}2.953 \\
*\end{array}$ & & \\
\hline $\mathrm{CA}$ & 0.912 & $\begin{array}{l}0.1 \\
27\end{array}$ & 7.181 & $\begin{array}{l}\text { Not } \\
\text { Norma } \\
1\end{array}$ & & $\begin{array}{l}-2.39 \\
1 *\end{array}$ & & \\
\hline $\mathrm{CS}$ & 3.310 & $\begin{array}{l}0.1 \\
27\end{array}$ & $\begin{array}{l}26.06 \\
3\end{array}$ & $\begin{array}{l}\text { Not } \\
\text { Norma } \\
1\end{array}$ & & & & $\begin{array}{l}6.0 \\
94\end{array}$ \\
\hline CL & 0.009 & $\begin{array}{l}0.1 \\
27\end{array}$ & 0.071 & $\begin{array}{l}\text { Norma } \\
1\end{array}$ & & & & \\
\hline $\mathrm{CP}$ & 1.690 & $\begin{array}{l}0.1 \\
27\end{array}$ & $\begin{array}{l}13.30 \\
7\end{array}$ & $\begin{array}{l}\text { Not } \\
\text { Norma } \\
1\end{array}$ & & $\begin{array}{l}2.899 \\
*\end{array}$ & & \\
\hline
\end{tabular}

Notes: $*$ Normal Distributed, TL $=$ Timeliness, $\mathrm{ACG}=$ Audit Committee Gender, ACE: Audit Committee Financial Expertise, ACA = Audit Committee Activity, $\mathrm{ACI}=$ Audit Committee Independence, ACS = Audit Committee Size, CA = Company Age, CS = Company Size, $\mathrm{CL}=$ Company Leverage, and $\mathrm{CP}=$ Company Profitability.

The second classical assumption is the multicollinearity problem. Gujarati (1995) defined multicollinearity as a situation in which two or more independent variables are highly correlated. There are a few techniques used to detect multicollinearity problems in the model, such as Variance Inflation Factor (VIF), Pearson Correlation Matrix, etc. Anderson, Sweeney, \& Williams (1996) argued that if the Pearson Correlation result is higher than 0.6, there would not be a multicollinearity problem. The result of the Pearson Correlation is presented in Table 3. It seems that there is no multicollinearity problems.

Table 3: Pearson Correlation

\begin{tabular}{llllllllll}
\hline & AC & ACE & AC & ACI & ACS & CA & CS & CL & C \\
& $\mathbf{G}$ & & A & & & & & & P \\
\hline AC & 1 & & & & & & & & \\
G & & & & & & & & & \\
AC & 0.05 & 1 & & & & & & & \\
E & 0 & & & & & & & & \\
AC & -0.0 & -0.0 & 1 & & & & & & \\
A & 50 & 45 & & & & & & & \\
A & 0.09 & -0.0 & -0.1 & 1 & & & & & \\
CI & 5 & 45 & 42 & & & & & & \\
AC & -0.0 & -0.1 & 0.14 & 0.17 & 1 & & & & \\
S & 56 & 41 & 9 & 3 & & & & & \\
C & 0.04 & 0.08 & 0.19 & 0.00 & 0.11 & 1 & & & \\
A & 7 & 6 & 6 & 8 & 5 & & & & \\
CS & -0.1 & 0.07 & 0.02 & -0.0 & -0.0 & -0.0 & 1 & & \\
& 21 & 7 & 3 & 73 & 72 & 45 & & & \\
CL & -0.0 & 0.02 & 0.09 & -0.1 & 0.02 & 0.13 & -0.0 & 1 & \\
& 08 & 4 & 4 & 38 & 4 & 0 & 23 & & \\
CP & 0.01 & 0.07 & 0.10 & -0.0 & 0.15 & 0.17 & -0.0 & -0.0 & 1 \\
& 4 & 3 & 1 & 15 & 0 & 0 & 22 & 31 & \\
\hline
\end{tabular}

Notes: $\mathrm{TL}=$ Timeliness, $\mathrm{ACG}=$ Audit Committee Gender, ACE: Audit Committee Financial Expertise, ACA = Audit Committee Activity, $\mathrm{ACI}=$ Audit Committee Independence, $\mathrm{ACS}=$ Audit Committee Size, $\mathrm{CA}=$ Company Age, $\mathrm{CS}=$ Company Size, $\mathrm{CL}=$ Company Leverage, and $\mathrm{CP}=$ Company Profitability.

The third classical assumption handled is the heteroscedaticity problem which is the most classical assumption violation in multi- variate analysis (Hair et al., 2014). This problem occurs when unequal variances exist in the model. Therefore, it must be solved before proceeding to the next procedure. Wooldridge (2003) argued that the White General Heteroscedasticity test can be applied to detect this problem. The result of heteroscedasticity using the White test shows that there is no such problem in the model since the p-value is greater than 0.05 (0.808). Autocorrelation problem is tested here because of the type of analysis used in this study. Having solved the several classical assumptions, the following procedure was used to test the hypothesis. Panel data analysis was applied using an OLS pooled, Random-fixed and Fixed-effect Model. Which model is better was determined by the difference group means between Pooled OLS vs. Fixed-effect, BreuschPagan test for Pool OLS vs. Random-effect and Hausman test (Hausman, 1978) for Random-effect vs. Fixed-effect. The regression result is demonstrated in Table 4.

Table 4: Regression Result

\begin{tabular}{lllllll}
\hline $\begin{array}{l}\text { Predictor Pooled OLS } \\
\text { Model }\end{array}$ & \multicolumn{3}{l}{$\begin{array}{l}\text { Random-Effec Fixed-Effect } \\
\text { t Model }\end{array}$} \\
\hline & Coef & P-value & Coef & P-value & Coef & P-value \\
Const & 0,99 & 0,30 & 0,57 & 0,59 & 43,58 & 0,00 \\
ACG & 0,24 & 0,36 & 0,26 & 0,34 & 0,47 & 0,46 \\
ACE & $-0,03$ & 0,85 & $-0,14$ & 0,47 & $-0,56$ & 0,18
\end{tabular}




$\begin{array}{lllllll}\text { ACA } & 0,50 & 0,00^{* * *} & 0,39 & 0,01^{* * *}-0,01 & 0,98 \\ \text { ACI } & -0,31 & 0,00^{* * *} & -0,26 & 0,01^{* * *}-0,05 & 0,78 \\ \text { ACS } & 1,26 & 0,05^{*} & 1,38 & 0,04^{* * *}-0,61 & 0,63 \\ \text { CA } & 0,37 & 0,06^{*} & 0,39 & 0,07^{*} & -11,23 & 0,00^{* * *} \\ \text { CS } & -0,52 & 0,09^{*} & -0,33 & 0,27 & -0,25 & 0,59 \\ \text { CL } & 0,59 & 0,09^{*} & 0,63 & 0,08^{*} & 0,19 & 0,78 \\ \text { CP } & 0,10 & 0,13 & 0,08 & 0,22 & 0,02 & 0,86 \\ \text { F sig } & 0.000 & & - & & 0.000 & \\ \text { R Square } & 0,212 & & - & & 0.868 & \\ \begin{array}{l}\text { Differenc } \\ \text { e }\end{array} & & & & & \\ \text { Group } & & & & & & \\ \text { Means } \\ \text { (p-value) } \\ \text { Breusch- }\end{array}$

Notes: ***,**, and $*$ is significant at $1 \%, 5 \%$, and $10 \%$. TL $=$ Timeliness, $\mathrm{ACG}=$ Audit Committee Gender, ACE: Audit Committee Financial Expertise, ACA = Audit Committee Activity, $\mathrm{ACI}=$ Audit Committee Independence, $\mathrm{ACS}=$ Audit Committee Size, CA = Company Age, CS = Company Size, $\mathrm{CL}=$ Company Leverage, and $\mathrm{CP}=$ Company Profitability.

Difference group means show that the fixed-effect model is preferred compared to the pooled OLS. However, the result of Breusch-Pagan test indicates that the Random-effect model is better than the Pooled OLS. The final test is between Random- effect vs. Fixed-effect model and the result shows that the Fixed- effect model is better. Therefore, we used the Fixed-effect model to interpret the effect of gender in the Audit Committee on financial reporting timeliness. From the Fixed-effect model, we can conclude that there is no effect of gender in the Audit Committee on timeliness of financial reporting. In fact, only one variable significantly influences financial reporting timeliness, i.e., company age.

The percentage of women on the Audit Committee (16\%) is higher than the percentage of women on the Supervisory Board and Board of Directors as identified by Ilona (2015). This difference may be caused by different periods during which Ilona (2015) carried out the investigation (2004 to 2010). However, this percentage is a little bit lower compared to the finding of Gavious et al. (2012), i.e., $19.2 \%$. This finding contradicts the argument that women on the governing board would have a positive impact on accounting outcomes, such as earnings quality (Gavious et al., 2012) and timeliness.

The insignificant role of women in the Audit Committee interms of the financial reporting proccess in Indonesia may be caused by the small number of women as Audit Committee members. In addition, the lack of financial or accounting expertise of women in the Audit Committee may have reduced the time taken for financial reporting in Indonesia's listed companies. Besides, gender in the Audit
Committee may limit board room cohesion (Adams \& Ferreira, 2009). In addition, women on the Audit Committee may hinder the decision-making process (Adams \& Ferreira, 2009). Further, gender diversity in Indonesian companies' audit commitees may be a signal of tokenism. The argument that the potential benefit of women may be fairly limited is also supported (Abdullah, 2014).

\section{CONCLUSION AND RECOMMENDATION}

Timeliness of the financial report is one of the qualitative attrib- utes of general purpose financial reports. Besides, an important attribute of timeliness is information content (Beaver, 1968), and the effect on company values (Chambers \& Penman, 1984; Givoly \& Palmon, 1984; Kross \& Schroeder, 1984). In addition, man- agement has incentives to exercise discretion over the timeliness of reporting (Ashton et al., 1989; Givoly \& Palmon, 1984) and the amount of asymmetric information between management and shareholders. In fact, timely reporting could enhance decision- making and reduce information asymmetry in emerging markets (Owusu-ansah, 2000). Moreover, it is an important device to mitigate insider trading, leaks and rumours in emerging capital markets (Owusu-ansah, 2000). Research on timeliness-corporate governance relationship has focused on board governance attributes, such as board independence as well as Audit Committee attributtes. However, these studies have failed to give attention to women in the Audit Committee. In addition, previous research in this area has been conducted on the Anglo Saxon two-tier board system and very little attention has been paid to the Continental European governance system, such as that used in Indonesia. Further, this system in Indonesia differs from the original European governance system implemented in the Netherlands. Therefore, this study investigates the role of gender in the Audit Committee and its influence on the timeliness of financial reporting by using Indonesia's listed companies in the period of 2014 and 2015. This study concludes that there is an insignificant effect of gender in the Audit Committee on the timeliness of financial reporting.

\section{ACKNOWLEDGMENT}

we thanks to the Rector of Universitas Bung Hatta and Universitas Putra Indonesia YPTK for significant supporting in term of finance and others.

\section{REFERENCES}

[1] Abbott, L. J., Parker, S., \& Peters, G. F. (2004). Audit commitee characteristics and restatements. Auditing: A Journal of Practice \& Theory, 23(1), 69-87.

[2] Abdelsalam, O. H., \& Street, D. L. (2007). Corporate governance and the timeliness of corporate internet reporting by U.K. listed companies. Journal of International Accounting, Auditing and Tax-ation, 16, 111-130. https://doi.org/10.1016/j.intaccaudtax.2007.06.001

[3] Abdullah, S. N. (2014). The causes of gender diversity in Malaysi- an large firms. Journal of Management \& Governance, 18(4), 1137-1159.

[4] Abernathy, J. L., Beyer, B., Masli, A., \& Stefaniak, C. (2014). The association between characteristics of audit committee 
accounting experts, audit committee chairs, and financial reporting timeliness. Advances in Accounting, Incorporating Advances in International Accounting, 30(2), 283-297. https://doi.org/10.1016/j.adiac.2014.09.001

[5] Abernathy, J. L., Beyer, B., Masli, A., \& Stefaniak, C. M. (2015). How the Source of Audit Committee Accounting Expertise Influ- ences Financial Reporting Timeliness. Current Issues in Auditing, 9(1), 1-9. https://doi.org/10.2308/ciia-51030

[6] Adams, R. B., \& Ferreira, D. (2009). Women in the boardroom and their impact on governance and performance. Journal of Financial Economics, 94(2)

291-309. https://doi.org/10.1016/i.jfineco.2008.10.007

[7] Ahmad-Zaluki, N. A. (2012). The pre- and post-IPOs gender composition of board of directors in Malaysia. Gender in Management:An International Journal, 27(7), 449-462. https://doi.org/10.1108/17542411211273441

[8] Al-Shaer, H., Salama, A., \& Toms, S. (2017). Audit committees and financial reporting quality. Journal of Applied Accounting Re-search, 18(1), 2-21. https://doi.org/10.1108/JAAR-10-2014-0114

[9] Alfraih, M. M. (2016). Corporate governance mechanisms and audit delay in a joint audit regulation. Journal of Financial Regulation and Compliance, 24(3), 292-316. https://doi.org/10.1108/JFRC-09-2015-0054

[10] Alkhatib, K., \& Marji, Q. (2012). Audit reports timeliness : Empiri- cal evidence from Jordan. In Procedia- social and Behavioural Sci-ences (Vol. 62, pp. 1342-1349). https://doi.org/10.1016/j.sbspro.2012.09.229

[11] Ammer, M. A., \& Ahmad-zaluki, N. A. (2017). The role of the gender diversity of audit committees in modelling the quality of management earnings forecasts of initial public offers in Malaysia. Gender in Management: An International Journal, 32(6), 420-440.

[12] Anderson, D. R., Sweeney, D. J., \& Williams, T. A. (1996). Statis- tics for business and economics. Minneapolis: West Publishing.

[13] Appiah, K. O., \& Amon, C. (2017). Board audit committee and corporate insolvency. Journal of Applied Accounting Research, 18(3), 298-316. https://doi.org/10.1108/JAAR-03-2015-0024

[14] Arayssi, M., Dah, M., \& Jizi, M. (2016). Women on boards, sustainability reporting and firm performance. Sustainability Account-ing, Management and Policy Journal, 7(3), 376-401.

[15] Ashton, R. H., Graul, P. R., \& Newton, J. D. (1989). Audit delay and the timeliness of corporate reporting. Contemporary Account- ing Research, 5(2), 657-673.

[16] Baatwah, S. R., Salleh, Z., \& Ahmad, N. (2013). Whether Audit Committee Financial Expertise Is the Only Relevant Expertise : A Review of Audit Committee Expertise and Timeliness of Financial Reporting. Issues in Social and Environmental Accounting, 7(2), 86-101.

[17] Baatwah, S. R., Salleh, Z., \& Ahmad, N. (2015). CEO characteris- tics and audit report timeliness: do CEO tenure and financial exper- tise matter? Managerial Auditing Journal, 30(8/9), 998-1022.

[18] Barnet, V., \& Lewis, T. (1994). Outlier in Statistical Data (3rd ed.) New York: Wiley.

[19] Beekes, W., Pope, P., \& Young, S. (2004). The Link Between Earn- ings Timeliness, Earnings Conservatism and Board Composition : evidence from the UK. CORPORATE GOVERNANCE, 12(1), 47-60.

[20] Betz, M., O'Connell, L., \& Shepard, J. M. (1989). Gender differ- ences in proclivity for unethical behavior. Journal of Business Eth-ics, 8(5), 321-324.

[21] Bin-Ghanem, H., \& Ariff, A. M. (2016). The effect of board of di- rectors and audit committee effectiveness on internet financial re- porting: Evidence from gulf co-operation council countries. Journal of Accounting in Emerging Economies, 6(4), 429-448.

[22] Carslaw, C. A. P. N., \& Kaplan, S. E. (1991). An Examination of Audit Delay : Further Evidence from New Zealand. Accounling and Business Research, 22(85), 21-32.

[23] Carter, D. A., D'Souza, F., Simkins, B. J., \& Simpson, W. G. (2010). The gender and ethnic diversity of US boards and board committees and firm financial performance. Corporate Governance, 18(5), 396-414. https://doi.org/10.1111/j.1467-8683.2010.00809.x

[24] Carter, D., Simkins, B., \& Simpson, W. (2003). Corporate Govern- ance, Board Diversity, and Firm Value. The Financial Review, Wiley Online Library, 38(1), 33-53. https://doi.org/10.1111/1540-6288.00034

[25] Chambers, A. E., \& Penman, S. H. (1984). Timeliness of Reporting and the Stock Price Reaction to Earnings Announcements. Journal of Accounting Research, 22(1), 21-47.

[26] Chandar, N., Chang, H., \& Zheng, X. (2012). Does overlapping membership on audit and compensation committees improve a firm's financial reporting quality? Review of Accounting and Finance, 11(2), 141-165. https://doi.org/10.1108/14757701211228192
[27] Cohen, J., Krishnamoorthy, G., \& Wright, A. (2004). THE CORPORATE GOVERNANCE MOSAIC AND FINANCIAL REPORTING QUALIT. Journal of Accounting Lliteratureliterature, 23, 87-152.

[28] Cooper, E. (2017). Corporate social responsibility, gender, and CEO turnover. Managerial Finance, 43(5), 528-544. https://doi.org/10.1108/MF-02-2016-0049

[29] Cullinan, C. P. (2003). Competing size theories and audit lag : Evi- dence from mutual fund audits. Journal of American Academy of Business, 3(1/2), 183-189.

[30] Daily, C. M., Certo, S. T., \& Dalton, D. R. (2000). The future of corporate women: Progress toward the executive suite and the boardroom? In Women on corporate boards of directors: International challenges and opportunities (pp. 11-23). Netherlands: Kluwer Academic Publishers.

[31] Dalton, D. R., \& Dalton, C. M. (2010). Women and corporate boards of directors: The promise of increased, and substantive, par- ticipation in the post Sarbanes-Oxley era. Business Horizons, 53(3), 257-268. https://doi.org/10.1016/j.bushor.2009.12.004

[32] DAVIES, B., \& WHITTRED, G. P. (1980). The Association Be- tween Selected Corporate: Attributes and Timeliness in Corporate: Reporting: Further Analysis. Abacus, 16(1), 48-60. https://doi.org/10.1111/j.1467-6281.1980.tb00085.x

[33] Defond, M. L., Hann, R. N., Xuesong, H. U., \& Engel, E. (2005). Does the market value financial expertise on audit committees of boards of directors? Journal of Accounting Research, 43(2), 153-204. https://doi.org/10.1111/j.1475-679x.2005.00166.x

[34] Dezoort, F. T. (1998). An analysis of experience effects on audit committee members' oversight judgments. Accounting, Organiza-tions and Society, 23(1), 1-21. https://doi.org/10.1016/S0361-3682(97)00029-9

[35] Erhardt, N. L., Werbel, J. D., \& Shrader, C. B. (2003). Board of Director Diversity and Firm Financial Performance. CORPORATE GOVERNANCE, 11(2), 102-111.

[36] Fama, E. F., \& Jensen, M. C. (1983). Separation of ownership and control. Journal of Law and Economics, 26(June), 32

[37] Francoeur, C., Labelle, R., \& Sinclair-Desgagné, B. (2008). Gender diversity in corporate governance and top management. Journal of Business $\quad$ Ethics, 81(1), 83-95. https://doi.org/10.1007/s10551-007-9482-5

[38] Gavious, I., Segev, E., \& Yosef, R. (2012). Female directors and earnings management in high-technology firms. Pacific Accounting Review (Vol. 24). https://doi.org/10.1108/01140581211221533

[39] Givoly, D., \& Palmon, D. (1984). Timeliness of annual earnings announcements: some empirical evidence. The Accounting Review, 57(3), 486-507.

[40] Grubbs, F. F. (1969). Procedures for Detecting Outlying Observa-tions in Samples. Tachometric (Vol. 11)

[41] Gujarati, D. (1995). Basic Econometric. Singapore: McGraw-Hill.

[42] Gul, F. A., Srinidhi, B., \& Ng, A. C. (2011). Does board gender diversity improve the informativeness of stock prices. Journal of Accounting and Economics, 51, 314-338.

[43] Hair, J. F., William, C., Babin, B. J., \& Anderson, R. E. (2014) Multivariate Data Analysis (7th Editio). Pearson Education Limited.

[44] Hakanson, N. H. (1977). Interim Disclosure and Public Forecasts : An Economic Analysis and a Framework for Choice. In The Accounting Review (Vol. 52, pp. 396-426).

[45] Hausman, J. A. (1978). Specification Tests in Econometrics. Econ ometrica, 46(6), 1251-1271.

[46] Hawarden, R. J., \& Marsland, S. (2011). Locating women board members in gendered director networks. Gender in Management:An $\begin{array}{llr}\text { International } & \text { Journal, } & \text { 53(8), }\end{array}$ https://doi.org/10.1108/17542411111183866

[47] Hsu, H. (2007). Boards of directors and audit committees in initial public offerings. DBA Dissertation. Nova Southeastern University.

[48] Huse, M., Nielsen, S. T., \& Hagen, I. M. (2009). Women and employee-elected board members, and their contributions to board control tasks. Journal of Business Ethics, 89(4), 581-597. https://doi.org/10.1007/s10551-008-0018-4

[49] Hyde, J. S., \& Kling, K. C. (2001). Women, motivation, and Achievement. Psychology of Women Quarterly, 25, 364-378.

[50] Ika, S. R., \& Ghazali, N. A. M. (2015). Audit committee effective- ness and timeliness of reporting: Indonesian evidence. Managerial Auditing Journal, 27(4), 403-424. https://doi.org/10.1108/MBE-09-2016-0047 
[51] Ilona, D. (2015). Directors' Diversity, Ownership Concentration and company performance in Indonesia listed companies. Universi- ti Utara Malaysia.

[52] Jaggi, B., \& Tsui, J. (1999). Determinants of audit report lag: fur- ther evidence from Hong Kong. Accounting and Business Research, 30(1), $17-28$.

[53] Jeffrey M. Wooldridge. (2003). Introductory Econometrics.

[54] Jensen, M., \& Meckling, W. (1976). Theory of the firm: managerial behavior, agency costs, and ownership structure. Journal of Finan- cial Economics, $3(4)$, $305-360$. https://doi.org/10.1017/CBO9780511817410.023

[55] Jin, Z., Song, S., \& Yang, X. (2014). The role of female directors in corporate governance investment in China. China Journal of Accounting Studies, 2(4), 323-344.

[56] Joecks, J., Pull, K., \& Vetter, K. (2013). Gender Diversity in the Boardroom and Firm Perfor- mance: What Exactly Constitutes a " Critical M ass "? Journal of Business Ethics, 118(1), 61-72.

[57] Kallamu, B. S., \& Saat, N. A. M. (2015). Audit committee attrib- utes and firm performance: evidence from Malaysian finance com- panies. Asian Review of Accounting, 23(3), 206-221.

[58] Kaplan, S., Pany, K., Samuels, J., \& Zhang, J. (2009). An examina- tion of the association between gender and reporting intentions for fraudulent financial reporting. Journal of Business Ethics, 87, 5-30.

[59] Klein, A. (2002). Audit committee, board of directorcharacteristics, and earnings management. Journal of Accounting and Economics, 33(3 SRC-GoogleScholar), 375-400.

[60] Kleinbaun, D. G., Kupper, L. L., Muller, K. E., \& Nizam, A. (1998). Applied Regression Analysis and Other Multivariate Methods (3rd editio). Pacific Grove: Duxbury Press.

[61] Kross, W., \& Schroeder, D. A. (1984). An Empirical Investigation of the Effect of Quarterly Earnings Announcement Timing on Stock Returns. Journal of Accounting Research, 22(1), 153-176.

[62] Lenard, M. J., Yu, B., York, E. A., \& Wu, S. (2014). Impact of board gender diversity on firm risk. Managerial Finance, 40(8), 787-803. https://doi.org/10.1108/MBE-09-2016-0047

[63] Lin, J. W., Li, J. F., \& Yang, J. S. (2006). The effect of audit com- mittee performance on earnings quality. Managerial Auditing Jour-nal, 21(9), 921-933. https://doi.org/10.1108/02686900610705019

[64] Manning, M. L., \& Munro, D. (2004). The business survey researcher's SPSS cookbook. New South Wales.

[65] McMullen, D. A. (1996). Audit committee performance: An investigation of the Consequences associated with audit committee. Auditing: A Journal of Practice \& Theory, 15(1), 87-96.

[66] Miethe, T. D., \& Rothschild, J. (1994). Whistleblowing and the Control of Organizational Misconduct. Sociological Inquiry, 64(3), 322-347.

[67] Moore, D. S., \& McCabe, G. P. (1999). Introduction to the Practice of Statistics (3rd ed.). New York: W. H. Freeman.

[68] Morrison, A. M., Randall, P. W., \& Van, E. V. (2004). The Center for Creative Leadership, Breaking the Glass Ceiling. Boston, MA.: Addison-Wesley.

[69] Nielsen, S., \& Huse, M. (2010). The contribution of women on boards of directors: Going beyond the surface. Corporate Govern-ance, $18(2)$, 136-148. https://doi.org/10.1111/j.1467-8683.2010.00784.x

[70] Niu, F. F. (2006). Corporate governance and the quality of account- ing earnings : a Canadian perspective. International Journal of Managerial Finance, 2(4), 302-327. https://doi.org/10.1108/17439130610705508

[71] Norusis, M. J. (1998). Guide to Data Analysis, SPSS 8.0. Upper Saddle River, New Jersey: Prentice-Hall, Inc.

[72] Offerman, L. R., \& Armitage, M. A. (1993). Stress and the woman manager: sources, health outcomes, and interventions. In Women in Management 4: Women and Work, Sage, Thousand Oaks (pp. 107-121).

[73] Owusu-ansah, S. (2000). Timeliness of corporate financial report- ing in emerging capital markets: empirical evidence from the Zim- babwe Stock Exchange. Accounting and Business Research, 30(3), 241-254.

[74] Owusu-Ansah, S., \& Leventis, S. (2006). Timeliness of Corporate Annual Financial Reporting in Greece. European Accounting Re-view, 15(2), 273-287.

[75] Pallant, J. (2007). SPSS Survival Manual: A Step by Step Guide to Data Analysis using SPSS for Windows (3rd edition, ) (3rd ed). New York: Open University Press.

[76] Pelled, L. H. (1996). Demographic Diversity, Conflict, and Work Group Outcomes: An Intervening Process Theory. Organization Science, 7(6), 615-631. https://doi.org/10.1287/orsc.7.6.615

[77] Ren, T., \& Wang, Z. (2011). Female participation in TMT and firm performance: evidence from Chinese private enterprises. Nankai

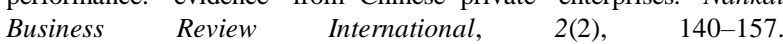
https://doi.org/10.1108/20408741111139918
[78] Rhee, K. S., \& Sigler, T. H. (2015). Untangling the relationship be- tween gender and leadership. Gender in Management: An Interna- tional Journal, 30(2), 109-134. https://doi.org/10.1108/GM-09-2013-0114

[79] Samaha, K., \& Khlif, H. (2017). Audit-related attributes, regulatory reforms and timely disclosure. Journal of Financial Reporting and Accounting, 15(2), https://doi.org/10.1108/JFRA-08-2015-0077

[80] Schmidt, J., \& Wilkins, M. S. (2013). Bringing Darkness to Light: The Influence of Auditor Quality and Audit Committee Expertise on the Timeliness of Financial Statement Restatement Disclosures. Auditing: A Journal of Practice \& Theory, 32(1), 221-244. https://doi.org/10.2308/ajpt-50307

[81] Srinidhi, B. I. N., Gul, F. A., \& Tsui, J. (2011). Female Directors and Earnings Quality. Contemporary Accounting Research, 28(5), 1610-1644. https://doi.org/10.1111/j.1911-3846.2011.01071.x

[82] Sulaiman, N. A. (2017). Oversight of audit quality in the UK: in- sights into audit committee conduct. Meditari Accountancy Re-search, 25(3), 351-367. https://doi.org/10.1108/MEDAR-08-2016-0074

[83] Tabacknick, B. G., \& Fidell, L. S. (1996). Using multivariate statis- tic (3rd ed.). New York: Harpour collings collers publishers

[84] Terjesen, S., Sealy, R., \& Singh, V. (2009). Women Directors on Corporate Boards: A Review and Research Agenda. Corporate Governance: An International Review, 17(3), 320-337. https://doi.org/10.1111/j.1467-8683.2009.00742.x

[85] Thiruvadi, S. (2012). Gender differences and audit committee dili- gence. Gender in Management: An International Journal, 27(6), 366-379. https://doi.org/10.1108/17542411211269310

[86] Vanasco, R. R. (1994). The Audit Committee: An International Perspective. Managerial Auditing Journal, 9(8), 18-42. https://doi.org/10.1108/02686909410071151

[87] Zahra, S. A., \& Pearce, J. A. (1989). Boards of directors and corpo- rate financial performance: A review and integrative model. Jour- nal of Management, 15(2), 291-334. https://doi.org/0803973233

\section{Authors Profile}

Zaitul, Economics Faculty, Universitas Bung Hatta, Padang, Indonesia.The research interests are corporate governance and Business. Administration.

Desi Ilona, Economics Faculty, Universitas Putra Indonesia YPTK, Padang, Indonesia, She is expert in Corporate Governance. 